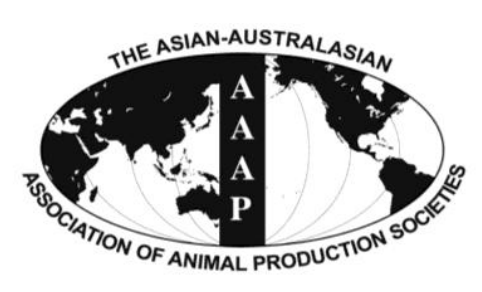

Open Access

Asian Australas. J. Anim. Sci.

Vol. 27, No. 8 : 1164-1173 August 2014

http://dx.doi.org/10.5713/ajas.2013.13770

\author{
www.ajas.info
}

pISSN 1011-2367 elSSN 1976-5517

\title{
Effect of Particular Breed on the Chemical Composition, Texture, Color, and Sensorial Characteristics of Dry-cured Ham
}

\author{
Pil Nam Seong, Kuyng Mi Park, Sun Moon Kang, Geun Ho Kang, Soo Hyun Cho, \\ Beom Young Park, and Hoa Van Ba* \\ Animal Products and Processing Division, National Institute of Animal Science, Suwon 441-706, Korea
}

\begin{abstract}
The present study demonstrates the impact of specific breed on the characteristics of dry-cured ham. Eighty thighs from Korean native pig (KNP), crossbreed (LandracexYorkshire) ${ }_{+} \times$Duroc $^{\wedge}$ (LYD), Berkshire (Ber), and Duroc (Du) pig breeds ( $\mathrm{n}=10$ for each breed) were used for processing of dry-cured ham. The thighs were salted with $6 \% \mathrm{NaCl}(\mathrm{w} / \mathrm{w})$ and $100 \mathrm{ppm} \mathrm{NaNO}_{2}$, and total processing time was 413 days. The effects of breed on the physicochemical composition, texture, color and sensory characteristics were assessed on the biceps femoris muscle of the hams. The results revealed that the highest weight loss was found in the dry-cured ham of LYD breed and the lowest weight loss was found in Ber dry-cured ham. The KNP dry-cured ham contain higher intramuscular fat level than other breed hams $(\mathrm{p}<0.05)$. It was observed that the dry-cured ham made from KNP breed had the lowest water activity value and highest salt content, while the LYD dry-cure ham had higher total volatile basic nitrogen content than the Ber and Du hams ( $\mathrm{p}<0.05$ ). Zinc, iron and total monounsaturated fatty acids levels were higher in KNP ham while polyunsaturated fatty acids levels were higher in Du ham when compared to other breed hams $(\mathrm{p}<0.05)$. Additionally, the KNP dry-cured ham possessed higher Commission International de l'Eclairage (CIE) a* value, while the Du dry-cured ham had higher $\mathrm{L}^{*}, \mathrm{CIE} \mathrm{b}^{*}$ and hue angle values $(\mathrm{p}<0.05)$. Furthermore, breed significantly affected the sensory attributes of dry-cured hams with higher scores for color, aroma and taste found in KNP dry-cured ham as compared to other breed hams $(\mathrm{p}<0.05)$. The overall outcome of the study is that the breed has a potential effect on the specific chemical composition, texture, color and sensorial properties of dry-cured hams. These data could be useful for meat processors to select the suitable breeds for economical manufacturing of high quality dry-cured hams. (Key Words: Breed, Dry-cured Ham, Texture, Color, Sensory)
\end{abstract}

\section{INTRODUCTION}

Dry-cured ham is one of the popular cured meat products with high storage-stability and typical sensory characteristics (Jimenez-Colmenero et al., 2010). Practically, dry-cured ham is a meat preservation process that allows safe ham storage for long periods. Mediterranean and European countries have a long-standing history of drycured ham production, where many types of dry-cured hams have been commercially produced and available on the markets with high commercial value (Resano et al., 2007). Formerly, dry-cured hams have usually been made from

\footnotetext{
* Corresponding Author: Hoa Van Ba. Tel: +82-31-290-1699, Fax: +82-31-290-1697, E-mail: hoasaudau_85@yahoo.com Submitted Nov. 28, 2013; Revised Mar. 11, 2014; Accepted Apr. 10, 2014
}

whole legs, sea salt and fresh mountain air, but nowadays dry-cured hams are made either with traditional (ambient curing) or modern processing technology (artificially change the temperature and humidity levels) or utilizing a combination of both the technologies (Ruiz et al., 1998; Arnau et al., 2003; Marusic et al., 2011).

Korea has good circumstances for making dry-cured ham, for instance; the ham resources are cheap and abundant. However, scanty information is available on the characteristics of Korean dry-cured ham. Furthermore, it has been already reported that the quality characteristics of dry-cured ham are markedly affected by a number of factors related to the processing technology and raw material (Jurado et al., 2007; Jimenez-Colmenero et al., 2010). In which, the processing technology (e.g., salting and ripening period etc) has been found to largely affect the 
physicochemical components, texture, appearance, sensory characteristics as well as safety of dry-cured ham (Andres et al., 2004; Ruiz-Ramirez et al., 2006; Jimenez-Colmenero et al., 2010; Garcia-Gil et al., 2012). While, for the raw material, for instance; intramuscular fat (IMF) content in meat has been reported to directly affect the texture and sensory characteristics of dry-cured ham (Gandemer, 2002; Gandemer, 2009). However, earlier studies on raw meat material have also found that the chemical composition, quality parameters as well as eating quality of pork meat are greatly affected by animal breed (Cameron et al., 1990; Gil et al., 2008; Meinert et al., 2008; Lee et al., 2012). Therefore, from the previous findings it is hypothesized that the raw pork from different breeds with differences in physicochemical composition may subsequently affect the quality characteristics of dry-cured ham.

Thus, the aim of the current work was to elucidate the effect of breed on the physicochemical composition, color, texture and sensory characteristics of dry-cured ham. The findings of the present research could provide useful information for meat processors to select the suitable raw breeds for economical manufacturing of high quality drycured ham.

\section{MATERIALS AND METHODS}

\section{Processing of dry-cured ham}

Forty female pigs from four different pure and cross breeds $(\mathrm{n}=10$ for each breed); Korean native pig (KNP), crossbreed (Landrace ${ }^{\lambda} \times$ Yorkshire $)+{ }^{\prime} \times$ Duroc $^{\lambda} \quad$ (LYD); Berkshire (Ber), and Duroc (Du) were used in the present investigation. The animals were reared in different pens at a local farm (Suwon, Korea) and were fed with the same commercial diet. The animals at 6 months of age with their live weights of about 80 to $120 \mathrm{~kg}$ were obtained from the farm and transported to an abattoir of the National Institute of Animal Science, Suwon, Korea under the same handling conditions and were slaughtered by conventional procedures. After $24 \mathrm{~h}$ of chilling at $4{ }^{\circ} \mathrm{C}, 80$ thighs were taken from the 40 pig carcasses, and immediately transferred to Meat Processing Laboratory where the hams were processed into dry cured hams. Salting of hams was carried out in a cooling room at $1{ }^{\circ} \mathrm{C}$ to $4^{\circ} \mathrm{C}$ and $85 \%$ to $90 \%$ relative humidity. The hams were salted by covering the lean part of the raw hams with a salt mixture containing $6 \%$ (w/w) $\mathrm{NaCl}$ and 100 ppm $\mathrm{NaNO}_{2}$. The salted hams were then left for 14 days at $4^{\circ} \mathrm{C}$ and $85 \%$ relative humidity. After completion of salting, all hams were washed with cold water to remove the excessive salt, placed in salting chambers and held for further 60 days under similar conditions (postsalting). Temperature was, thereafter, increased from 4 to $20^{\circ} \mathrm{C}$ during 60 days, while relative humidity was progressively reduced from $85 \%$ to $65 \%$. Thereafter, all ham samples were hung and left for 77 days at $28 \pm 1^{\circ} \mathrm{C}$ (drying phase). Finally, the hams were ripened for 202 days at $15 \pm 0.5^{\circ} \mathrm{C}$. Total processing time was 413 days. The basic processing of dry-cured hams is shown in Figure 1A. The weights of ham samples before salting and
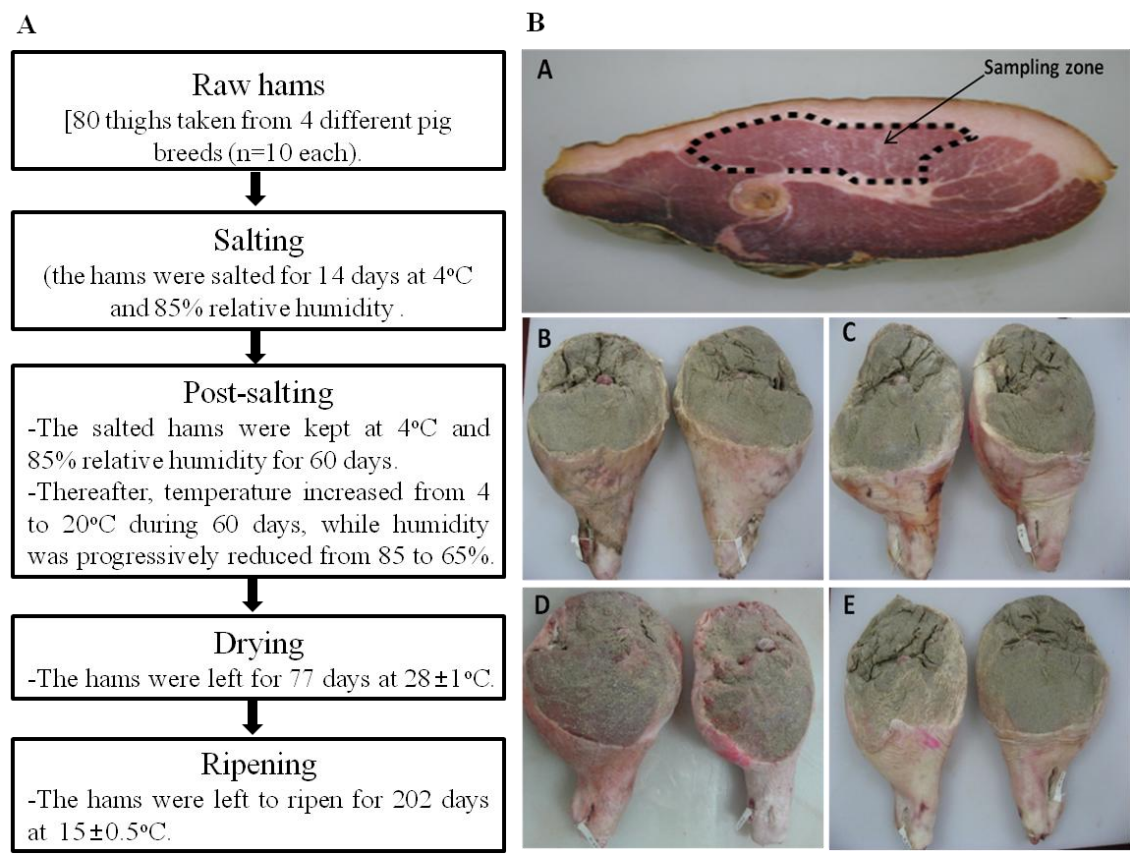

Figure 1. (A) the basic processing processes of dry-cured hams, (B) representative images of dry-cured hams from four different breeds. Location of sampling zone (biceps femoris muscle) within a cross-section of a dry-cured ham used for the present investigation (A), Duroc ham (B), Berkshire ham (C), Korean native pig ham (D) and LandracexYorkshirexDuroc ham. 
after ripening period were taken to calculate weight loss. Biceps femoris muscle samples were removed from the drycured hams (Figure 1B) and were stored at $-80^{\circ} \mathrm{C}$ till used for analyses of physicochemical composition, color, texture and sensory traits.

\section{Physicochemical composition}

The $\mathrm{pH}$ of biceps femoris muscle was measured in triplicates following the procedure of Bendall (1973) using a portable $\mathrm{pH}$ meter (Sentron Argus-X, Roden, Netherland).

Moisture, protein, intramuscular fat, $\mathrm{NaNO}_{2}$ and ash content were determined according to the procedures recommended by the AOAC international method (1995).

Water activity $\left(\mathrm{a}_{\mathrm{w}}\right)$ of the biceps femoris muscle was determined at $25^{\circ} \mathrm{C}$ with a Novasina measuring instrument, model AW SPRINT-TH 300 (Pfaffikon, Switzerland). Calibration was done by using several saturated solutions of known $a_{\mathrm{w}}$. Salt content (\% wet matter) was measured using a salinity meter (TM 30D, Takemura Electric Works Ltd., Tokyo, Japan).

Total volatile basic nitrogen (TVBN) content was determined following the method of Min et al. (2007) with suitable modifications. Briefly, biceps femoris muscle (10 g each) was homogenized with $50 \mathrm{~mL}$ of distilled water and filtered through Whatman filter paper (No.1) (AEC scientific Co., Seoul, Korea). The filtrate (1 mL each) was placed into the outer space of the Conway tool and $1 \mathrm{~mL}$ of $0.01 \mathrm{~N} \mathrm{H}_{3} \mathrm{BO}_{3}$ and 2 to 3 drops of Conway reagent $(0.066 \%$ methyl red: $0.066 \%$ bromocresol green, $1: 1)$ were also added to the inner space. Then $1 \mathrm{~mL}$ of $50 \% \mathrm{~K}_{2} \mathrm{CO}_{3}$ was added to the outer space of the Conway tool and was sealed immediately. The sealed Conway tool was incubated at $37^{\circ} \mathrm{C}$ for $120 \mathrm{~min}$ on a shaker. Finally, different volumes of $0.02 \mathrm{~N} \mathrm{H}_{2} \mathrm{SO}_{4}$ were added to the inner space to calculate the TVBN in the sample which was expressed as mg TVBN/100 g dry cured ham sample.

The mineral content of the samples was determined by following the AOAC international method (2000). Briefly, biceps femoris muscle (5 g each) was destroyed by dry ashing in a microwave ashing oven (Lilienthal, Bremen, Germany) for $12 \mathrm{~h}$ with a final temperature of $600^{\circ} \mathrm{C}$. The ash was dissolved with $10 \mathrm{~mL}$ of $\mathrm{HCl}$ and distilled water $(1: 1 \mathrm{v} / \mathrm{v})$ solution and was then filtered through Whatman filter paper (No.6). Minerals including $\mathrm{Na}$ (selected wavelength $588.9 \mathrm{~nm}), \mathrm{K}(766.5 \mathrm{~nm}), \mathrm{Ca}(422.7 \mathrm{~nm}), \mathrm{Mg}$ $(285 \mathrm{~nm}), \mathrm{P}(470 \mathrm{~nm}), \mathrm{Fe}(248.3 \mathrm{~nm})$, and $\mathrm{Zn}(213.9 \mathrm{~nm})$, $\mathrm{Mn}(279.5 \mathrm{~nm}), \mathrm{Cu}(324.7 \mathrm{~nm})$ and $\mathrm{Cr}(357.9 \mathrm{~nm})$ were determined by inductively coupled plasma/optical emission spectrophotometer (ICP/OES) (Spectro, Boschstr, Kleve, Germany). A calibration curve was prepared for each element.

Relative percentage of fatty acids in biceps femoris muscle was determined following our standardized method
(Ba et al., 2012).

\section{Texture measurement}

The texture properties were analyzed following the procedure of Ramirez and Cava (2008) using a texture analyzer (Instron model 4465, Instron Corp, High Wycombe, UK). Briefly, the biceps femoris muscle samples were cut into cubes of $2 \mathrm{~cm} \times 2 \mathrm{~cm} \times 2.5 \mathrm{~cm}$. The cube was axially compressed twice until reaching each time $80 \%$ of its initial height. The speed of load cell was set at 120 $\mathrm{mm} / \mathrm{min}$ and the following parameters were calculated: hardness $(\mathrm{kg})$, springiness $(\mathrm{mm})$, cohesiveness, gumminess $(\mathrm{kg})$ and chewiness $(\mathrm{kg} \times \mathrm{mm})$.

\section{Instrumental color measurement}

Color parameters of the dry-cured hams were measured across the cut surface of biceps femoris muscle at the end of processing (413 days) using a Minolta Chroma Meter CR400 (Osaka, Japan). Color was expressed according to the Commission International de l'Eclairage (CIE) system and reported as CIE L* (lightness), CIE a* (redness), CIE b* (yellowness), chroma and hue angle $\left(\mathrm{h}^{\circ}\right)$. In which the chroma and hue angle were calculated as $\left(a *^{2}+b^{2}\right)^{0.5}$ and $\tan ^{-1}\left(b^{*} / a^{*}\right)$, respectively. Each value was the mean of the readings taken at five different locations on the freshly cut surface of each sample after $30 \mathrm{~min}$ of blooming.

\section{Sensory evaluation}

Sensory properties of dry-cured hams obtained from four different pig breeds were evaluated by a trained panel members $(\mathrm{n}=8)$, using a descriptive analysis method as described by Ruiz et al. (1998) with suitable modifications. The panelists consisted of two males and six females with an average age of 30 to 35 years and were the members of the National Institute of Animal Science, Suwon, Korea. Before the sensory evaluation, the panelists had been trained for 6 months (once per every two weeks interval for $2 \mathrm{~h}$ ) to recognize the individual aroma and taste detection thresholds. Additionally, the panelists also participated in sensory evaluation of dry-cured hams of different pig breeds for further 6 months. The sensory samples were randomly allotted in 10 sessions; each session had 8 panelists and each panelist evaluated 8 sensory samples. Approximately 10 thin slices $(0.5 \mathrm{~mm}$ thick) were made from each biceps femoris muscle sample using a knife. Eight representative slices of about $10 \mathrm{~g}$ for each sample were finally chosen and immediately dispensed on individual plates and served to the panelists. The slices of the samples were evaluated by panelists for color, taste (intensity of overall taste) and aroma (level of overall odor before eating) using a $10 \mathrm{~cm}$ unstructured line scale. The temperature of the sensorial samples at the time of serving was about $20^{\circ} \mathrm{C}$. At the end of the evaluation, the panelists 
Table 1. Weight loss of dry-cured hams from four different pig breeds during processing $(\mathrm{n}=10)$

\begin{tabular}{|c|c|c|c|c|}
\hline \multirow{2}{*}{ Item } & \multicolumn{4}{|c|}{ Breed } \\
\hline & KNP & LYD & Ber & $\mathrm{Du}$ \\
\hline${\text { Weight of raw ham }(\mathrm{kg})^{1}}^{1}$ & $5.90 \pm 0.13^{\mathrm{c}}$ & $9.73 \pm 0.21^{b}$ & $10.88 \pm 0.18^{\mathrm{a}}$ & $11.17 \pm 0.19^{\mathrm{a}}$ \\
\hline Weight of dry-cured ham $(\mathrm{kg})^{2}$ & $3.54 \pm 0.10^{\mathrm{c}}$ & $5.45 \pm 0.17^{\mathrm{b}}$ & $7.21 \pm 0.12^{\mathrm{a}}$ & $6.89 \pm 0.12^{\mathrm{a}}$ \\
\hline Total weight loss $(\mathrm{kg})^{3}$ & $2.36 \pm 0.07^{\mathrm{c}}$ & $4.28 \pm 0.17^{\mathrm{a}}$ & $3.67 \pm 0.09^{\mathrm{b}}$ & $4.28 \pm 0.08^{\mathrm{a}}$ \\
\hline Total weight loss $(\%)^{4}$ & $40.00 \pm 0.83^{\mathrm{b}}$ & $43.95 \pm 1.42^{\mathrm{a}}$ & $33.73 \pm 0.56^{\mathrm{c}}$ & $38.28 \pm 0.27^{\mathrm{b}}$ \\
\hline Yield $(\%)^{5}$ & $60.00 \pm 0.83^{\mathrm{b}}$ & $56.05 \pm 1.42^{\mathrm{c}}$ & $66.27 \pm 0.56^{\mathrm{a}}$ & $61.72 \pm 0.27^{b}$ \\
\hline
\end{tabular}

KNP, Korean native pig; LYD, (Landrace $\times$ Yorkshire) $9 \times$ Duroc ${ }^{\wedge}$; Ber, Berkshire; Du, Duroc.

${ }^{1}$ The weights of raw thighs used for processing of dry-cure ham.

${ }^{2}$ Weights of dry-cure hams determined at the end of ripening period (413 days).

${ }^{3}$ The weights lost throughout the processing periods.

${ }^{4}$ Percentages of weights lost throughout the processing periods.

${ }^{5}$ Yield percentages of dry-cured hams at the end of ripening (413 days).

Means in the same row with different superscripts $(a, b, c)$ are significantly different $(\mathrm{p}<0.05)$.

were asked to refresh their mouth with drinking distilled water and salt-free crackers.

\section{Statistic analysis}

The effect of different breeds (KNP, LYD, Ber, and Du) on the chemical composition, texture, color and sensorial characteristics of dry-cured ham was analyzed by a twoway analysis of variance using the General Linear Model procedure of SAS (Statistic Analysis System Institute, Cary, NC, USA, 2007). All raw data were collected using Microsoft Office Excel 2007 and subjected to the statistic analysis. Mean values of the measurements were compared using the Duncan's multiple-range test at the significance level of 0.05 .

\section{RESULTS OF DISCUSSION}

\section{Effect of breed on physicochemical and nutritional composition}

Weight loss of dry-cured hams from four different breeds at different processing periods has been summarized in Table 1. The average initial weight of the thighs used for processing of dry-cured hams were the highest for $\mathrm{Du}$ $(11.17 \pm 0.19 \mathrm{~kg})$ and Ber $(10.88 \pm 0.18 \mathrm{~kg})$, followed by LYD $(9.73 \pm 0.21 \mathrm{~kg})$ and $\mathrm{KNP}(5.90 \pm 0.13 \mathrm{~kg})$. At the end of processing; the average weight of dry-cured hams showed variations among the breeds. For instance, the weights of Ber ham $(7.21 \pm 0.12 \mathrm{~kg})$ and Du ham $(6.89 \pm 0.12 \mathrm{~kg})$ were significantly $(\mathrm{p}<0.05)$ higher than that of LYD $(5.45 \pm 0.17$ $\mathrm{kg})$ and $\mathrm{KNP}(3.54 \pm 0.10 \mathrm{~kg})$ hams. The weight loss was highest in the ham of LYD breed $(43.95 \pm 1.42 \%)$ which corresponds to the lowest yield $(56.05 \pm 1.42 \%)$; while lowest weight loss was in the ham of Ber breed $(33.73 \pm 0.56 \%)$ with the highest yield $(66.27 \pm 0.56 \%)$. Thus, from the obtained results it appears that the sample size (initial weight) is not related to the weight loss. No differences among the hams of KNP and Du breeds were observed for the weight loss and the yield percentage ( $>0.05$ ). Previous studies have also demonstrated that the weight loss is affected by a number of factors such as; feeding diet and processing condition (Isabel et al., 1999; Arnau et al., 2003). In the present study all pig breeds were raised under the same condition and processed into drycured hams with the same technology, therefore the difference observed in weight loss was likely related to breed effect.

Proximate compositions of the dry-cured hams from four breeds are shown in Table 2. Moisture content is considered as an indicator of the degree of drying as well as the quality and shelf-stability of dry-cured ham. The moisture content of KNP ham was lower than that of the other ham breeds $(\mathrm{p}<0.05)$. While, no differences in the moisture content among the hams of LYD, Ber, and Du breeds were observed in the present study. Ramirez and Cava (2008) reported higher moisture values $(54.6 \%$ to $56.7 \%$ ) for the dry-cured hams of Iberian $\times$ Duroc pig breed at 22 months of ripening period.

The IMF content plays a very important role in

Table 2. Proximate compositions of dry-cured hams processed from four different pig breeds $(n=10)$

\begin{tabular}{lcccc}
\hline \multirow{2}{*}{ Content } & \multicolumn{3}{c}{ Breed } \\
\cline { 2 - 5 } & KNP & LYD & Ber & Du \\
\hline Moisture (\%) & $39.17 \pm 0.76^{\mathrm{b}}$ & $45.73 \pm 1.65^{\mathrm{a}}$ & $48.32 \pm 1.87^{\mathrm{a}}$ & $49.84 \pm 1.38^{\mathrm{a}}$ \\
IMF (\%) & $9.73 \pm 0.98^{\mathrm{a}}$ & $7.77 \pm 0.80^{\mathrm{ab}}$ & $7.16 \pm 1.22^{\mathrm{ab}}$ & $6.02 \pm 0.76^{\mathrm{b}}$ \\
Protein (\%) & $42.70 \pm 1.43$ & $43.05 \pm 1.92$ & $40.03 \pm 1.69$ & $42.22 \pm 1.42$ \\
Ash (\%) & $1.63 \pm 0.13^{\mathrm{a}}$ & $1.45 \pm 0.05^{\mathrm{ab}}$ & $1.31 \pm 0.08^{\mathrm{b}}$ & $1.44 \pm 0.04^{\mathrm{ab}}$ \\
\hline
\end{tabular}

KNP, Korean native pig; LYD, (Landrace $\times$ Yorkshire) $Q \times$ Duroc ${ }^{\wedge}$; Ber, Berkshire; Du, Duroc; IMF, intramuscular fat.

Means in the same row with different superscripts $(a, b)$ are significantly different $(\mathrm{p}<0.05)$. 
contribution to the appearance, texture and sensory characteristics of dry-cured ham (Ventanas et al., 2007; Jimenez-Colmenero et al., 2010). The present results showed that the dry-cured ham of KNP had the highest IMF level $(9.73 \pm 0.98 \%)$, whereas, the ham of Du breed had the lowest IMF $(6.02 \pm 0.76 \%)$. The level of IMF in the drycured ham of KNP was similar to that reported for the Iberian ham (Ventanas et al., 2007) but much higher than the IMF levels reported for other hams such as Serrano and Bayonne (Gandemer, 2009). A number of reports have shown that diet/feeding system greatly affects the IMF content of dry-cured hams (Ventanas et al., 2006; Ventanasb et al., 2007), suggesting that the pre-harvest factors play an important role in accumulation of IMF content in muscle tissue which is responsible for the differences in IMF contents between the dry-cured hams. Alternatively; the protein contents ranged from $40.03 \pm 1.69 \%$ to $43.05 \pm 1.92 \%$ between dry-cured hams which are similar the values (41.43\%) reported by Marusic et al. (2011) for the Istrian dry-cured ham. However, no differences in the protein content among the dry-cured hams were observed in the present study ( $p>0.05)$. The ash content is also an important factor that reflects the nutritional value, quality and physicochemical properties of foods (Keran et al., 2009). The ash content in the dry-cured ham of KNP $(1.63 \pm 0.13 \%)$ was significantly higher than the value $(1.31 \pm 0.08 \%)$ of Ber ham. In contrast, no differences in the ash content were observed among the hams of Du, Ber, and LYD breeds. Importantly, it was observed that the ash content in drycured ham of KNP was higher than the ash content reported by Marusic et al. (2011).

Chemical parameters of dry-cured hams are summarized in Table 3. No prominent differences $(\mathrm{p}>0.05)$ in the $\mathrm{pH}$ value were found among the dry-cured hams of four breeds, indicating that the glycolysis taking place in these hams during processing was similar for the all breeds. The $\mathrm{pH}$ values of the dry-cured hams ranged from 6.54 to 6.72 , which is similar to the values of reported for other hams in the literature (Arnau et al., 2003). Present results also depict that the TVBN shows variations among the dry-cured hams from different breeds. The TVBN content in the dry-cured hams of LYD breed was significantly $(\mathrm{p}<0.05)$ higher than that in dry-cured hams of Ber and Du breeds; however, no differences in the TVBN contents among the hams of KNP, Ber and Du breeds were observed. The TVBN content contains mainly ammonia, trimethylamine and dimethylamine, and is considered as the important index of pork's freshness (Min et al., 2007). The level of TVBN content increases during spoilage either by bacteria or enzymic degradation (Cai et al., 2011). Also, in the present study the bacterial and enzymatic action might be responsible for the variations in the TVBN content of different ham breeds. Cilla et al. (2005) reported that the TVBN level increases linearly with the increasing ripening time in dry-cured ham.

Salt $(\mathrm{NaCl})$ is an important component in the salting phase, besides producing typical taste it also provides stability against microbiological degradation through reduction of water activity in dry-cured ham. A low salt content may result in texture defects and also shortens the shelf-stability (Parolari et al., 1994; Ruiz-Ramirez et al., 2006). In the present study, the salt content showed great variation among the ham breeds; particularly the dry-cured ham of KNP had the highest salt content $(7.31 \pm 0.33 \%)$, followed by LYD (4.79 \pm 0.47$)$ and Du ham $(3.22 \pm 0.43 \%)$. Our results indicate that the salt penetrates and is absorbed into the biceps femoris muscle of KNP breed faster than other ham breeds. This is probably due to the lower weight (thinness of muscle) of leg samples of KNP. Whereas the samples of other breeds have thick muscles which make salt absorption slower. Conclusively; our results suggest that the processing technology (e.g., salt level and so on) should be taken into account and must be suitably modulated for each kind of raw material (breed). In the processing of dry-cured ham it is necessary to reduce water activity to stabilize the products, and water activity is determined by the amount of salt content in the liquid phase (Comaposada et al., 2000). We observed that the water activity of dry-cured ham was affected by breed; the dry-cured ham of KNP had the lowest water activity value $(0.84 \pm 0.01)$ whereas the hams of Ber and $\mathrm{Du}$ breeds had the highest water activity values $(0.91 \pm 0.01$ and $0.91 \pm 0.01$, respectively). These results are consistent with salt content in the dry-cured hams of the breeds (Table 2).

Table 3. Chemical parameters of dry-cured hams processed from four different pig breeds $(\mathrm{n}=10)$

\begin{tabular}{lrrrr}
\hline \multirow{2}{*}{ Item } & \multicolumn{3}{c}{ Breed } \\
\cline { 2 - 5 } & \multicolumn{1}{c}{ KNP } & \multicolumn{1}{c}{ LYD } & \multicolumn{1}{c}{ Ber } \\
\hline $\mathrm{pH}$ & $6.54 \pm 0.04$ & $6.72 \pm 0.08$ & $6.58 \pm 0.06$ & $6.57 \pm 0.05$ \\
Water activity & $0.84 \pm 0.01^{\mathrm{c}}$ & $0.89 \pm 0.01^{\mathrm{b}}$ & $0.91 \pm 0.01^{\mathrm{ab}}$ & $0.91 \pm 0.00^{\mathrm{ab}}$ \\
Salt content (\% wet matter) & $7.31 \pm 0.33^{\mathrm{a}}$ & $4.79 \pm 0.47^{\mathrm{b}}$ & $3.66 \pm 0.52^{\mathrm{bc}}$ & $3.22 \pm 0.43^{\mathrm{c}}$ \\
$\left.\mathrm{TVBN}^{\mathrm{b} g} \%\right)$ & $130.08 \pm 8.69^{\mathrm{ab}}$ & $148.31 \pm 8.55^{\mathrm{a}}$ & $123.37 \pm 8.10^{\mathrm{b}}$ & $121.59 \pm 7.19^{\mathrm{b}}$ \\
$\mathrm{NaNO}_{2}(\mathrm{ppm})$ & $0.38 \pm 0.11^{\mathrm{ab}}$ & $0.37 \pm 0.14^{\mathrm{ab}}$ & $0.26 \pm 0.07^{\mathrm{b}}$ & $0.66 \pm 0.17^{\mathrm{a}}$ \\
Calorie $(\mathrm{kcal} / \mathrm{g})$ & $3.66 \pm 0.09^{\mathrm{a}}$ & $3.12 \pm 0.12^{\mathrm{b}}$ & $3.03 \pm 0.10^{\mathrm{b}}$ & $2.90 \pm 0.09^{\mathrm{b}}$ \\
\hline
\end{tabular}

KNP, Korean native pig; LYD, (Landrace $\times$ Yorkshire) $q \times$ Duroc $^{\wedge}$; Ber, Berkshire; Du, Duroc; TVBN, total volatile basic nitrogen.

Means in the same row with different superscripts $(a, b, c)$ are significantly different $(p<0.05)$. 
Nitrites are widely used as a reservoir for the cured meat products including dry-cured hams, because they have a powerful preservative effect and color stability (Honikel, 2008). Our results showed that the amount of $\mathrm{NaNO}_{2}$ in the dry-cured hams vary among the breeds; the dry-cured ham of $\mathrm{Du}$ breed had the highest $\mathrm{NaNO}_{2}$ content $(0.66 \pm 0.17$ ppm) whereas the dry-cured ham of Ber breed had the lowest $\mathrm{NaNO}_{2}$ content $(0.26 \pm 0.07 \mathrm{ppm})$. This means that the penetration and absorption of $\mathrm{NaNO}_{2}$ into the lean tissue differs among the breeds and this was in contrast to the absorption pattern of $\mathrm{NaCl}$ into the lean tissues as discussed above. The dry-cured ham of KNP contained significantly $(\mathrm{p}<0.05)$ higher calories $(3.66 \pm 0.09 \mathrm{kcal} / \mathrm{g})$ than the hams of other breeds. This could be due to the higher level of IMF content present in the KNP.

Minerals are the important micronutrients which provide remarkable benefits to humans; the dietary mineral supplements play a vital role in maintaining human health (Tapiero and Tew, 2003). The mineral content of the drycured hams of four selected breeds is summarized in Table 4. Our results depict that potassium, sodium, iron, manganese and zinc levels in dry-cured hams from different breeds were different. Whereas, the other minerals such as calcium, phosphorous, magnesium and copper were similar in all ham breeds $(p>0.05)$. The relative percentage/or amounts of these minerals in the dry-cured hams were in the limits as reported in previous studies (Jimenez-Colmenero et al., 2010). Especially, it was observed that the dry-cured ham of KNP contained higher amount of iron and zinc than hams of other breeds. The present results clearly indicated that the dry-cured ham is a rich source of minerals. The variations in the amount of different minerals in different breeds could be attributed to the genetic differences of the breeds which influence their capacity to absorb and accumulate the minerals into their tissues.

The relative percentage of fatty acid profiles in the drycured hams of four breeds is shown in Table 5. Our results depict differences in the fatty acids in dry-cured hams of different breeds. Oleic acid (C18:1n9) was the most abundant monounsaturated fatty acid found in all ham breeds in which the KNP ham had higher level of C18:1n9. Earlier workers (Ruiz-Carrascal et al., 2000) have reported that the high IMF content gives a high proportion of $\mathrm{C} 18: 1 \mathrm{n} 9$ and the level of $\mathrm{C} 18: 1 \mathrm{n} 9$ positively correlates to the oiliness and brightness of dry-cured ham. Whereas, the dry-cured ham of Du breed contained higher levels of linoleic acid (C18:2n6), linolenic acid (C18:3n3) as well as total polyunsatured fatty acid (PUFA) levels. High levels of PUFAs have also been reported to have a negative effect on the oiliness and brightness of dry-cured ham (RuizCarrascal et al., 2000). A number of studies have indicated that diet/feeding system and processing methodology significantly affects the levels of fatty acids in various drycured ham types (Isabel et al., 1999; Pastorelli et al., 2003; Santos et al., 2008). In the present study we kept the aforementioned factors constant for the selected breeds but still observed a great variation in the level of fatty acids among the breeds.

\section{Effect of breed on texture}

It was observed that the breed significantly affects the texture traits of dry-cured hams (Table 6). Particularly, the dry-cured ham of KNP showed higher values of springiness, gumminess and chewiness, as compared to the other breed hams. Especially, the gumminess and chewiness values of dry-cured ham of KNP were several times greater than that of the other ham breeds. No differences among the hams of LYD, Ber, and Du breeds were observed for the hardness, gumminess and chewiness $(\mathrm{p}>0.05)$, whereas the springiness of LYD ham was significantly $(\mathrm{p}<0.05)$ higher than hams of Ber and Du breeds. Many factors (e.g., physicochemical properties of muscle and processing methods) may affect the textures of dry-cured ham for instance; Ruiz-Carrascal et al. (2000) and Gandemer (2009) found that the IMF content had a positive effect on the texture of dry-cured ham. While, earlier studies have demonstrated that levels of PUFAs had negative effect on the texture (e.g., oiliness and brightness) of dry-cured ham

Table 4. Mineral content $(\mathrm{mg} / \mathrm{kg})$ in the dry-cured hams processed from four different pig breeds $(\mathrm{n}=10)$

\begin{tabular}{lcccc}
\hline \multirow{2}{*}{ Mineral } & \multicolumn{3}{c}{ Breed } \\
\cline { 2 - 5 } & KNP & LYD & Ber & Du \\
\hline $\mathrm{Ca}$ & $20.0 \pm 1.0$ & $20.0 \pm 1.0$ & $20.0 \pm 1.0$ & $20.0 \pm 1.0$ \\
$\mathrm{P}$ & $3,100 \pm 100$ & $3,100 \pm 100$ & $2,900 \pm 100$ & $3,200 \pm 100$ \\
$\mathrm{~K}$ & $6,700 \pm 200$ & $5,800 \pm 400^{\mathrm{b}}$ & $5,300 \pm 300^{\mathrm{b}}$ & $5,400 \pm 200^{\mathrm{b}}$ \\
$\mathrm{Na}$ & $22,200 \pm 120^{\mathrm{a}}$ & $16,600 \pm 400^{\mathrm{b}}$ & $15,600 \pm 900^{\mathrm{bc}}$ & $14,200 \pm 400^{\mathrm{c}}$ \\
$\mathrm{Mg}$ & $20.0 \pm 1.0$ & $20.0 \pm 1.0$ & $20.0 \pm 1.0$ & $20.0 \pm 1.10$ \\
$\mathrm{Fe}$ & $26.20 \pm 2.48^{\mathrm{a}}$ & $25.20 \pm 2.57^{\mathrm{a}}$ & $18.33 \pm 2.05^{\mathrm{b}}$ & $14.81 \pm 1.33^{\mathrm{b}}$ \\
$\mathrm{Mn}$ & $0.22 \pm 0.04^{\mathrm{b}}$ & $0.28 \pm 0.06^{\mathrm{ab}}$ & $0.21 \pm 0.04^{\mathrm{b}}$ & $0.41 \pm 0.07^{\mathrm{a}}$ \\
$\mathrm{Zn}$ & $45.52 \pm 2.15^{\mathrm{a}}$ & $32.92 \pm 1.57^{\mathrm{b}}$ & $34.62 \pm 1.98^{\mathrm{b}}$ & $30.01 \pm 0.86^{\mathrm{b}}$ \\
$\mathrm{Cu}$ & $2.24 \pm 0.43$ & $2.09 \pm 0.28$ & $2.00 \pm 0.25$ & $2.18 \pm 0.32$ \\
\hline $\mathrm{KNP} K o n$
\end{tabular}

KNP, Korean native pig; LYD, (Landrace $\times$ Yorkshire) $q \times$ Duroc ${ }^{\wedge}$; Ber, Berkshire; Du, Duroc.

Means in the same row with different superscripts $(a, b, c)$ are significantly different $(p<0.05)$. 
Table 5. Relative percentage of fatty acids in dry-cured hams processed from four different pig breeds $(\mathrm{n}=10)$

\begin{tabular}{lcccc}
\hline \multirow{2}{*}{ Fatty acid } & \multicolumn{3}{c}{ Breed } & Du \\
\cline { 2 - 5 } C14:0 & KNP & LYD & Ber & $1.17 \pm 0.03^{\mathrm{c}}$ \\
C16:0 & $1.31 \pm 0.04^{\mathrm{b}}$ & $1.49 \pm 0.04^{\mathrm{a}}$ & $23.07^{\mathrm{ab}}$ & $22.73 \pm 0.26^{\mathrm{b}}$ \\
C16:1n7 & $24.67 \pm 0.36^{\mathrm{a}}$ & $23.51 \pm 0.28^{\mathrm{b}}$ & $25.07 \pm 0.38^{\mathrm{a}}$ & $2.65 \pm 0.11^{\mathrm{b}}$ \\
C18:0 & $2.98 \pm 0.08^{\mathrm{b}}$ & $2.95 \pm 0.11^{\mathrm{b}}$ & $3.65 \pm 0.20^{\mathrm{a}}$ & $11.40 \pm 0.33$ \\
C18:1n9 & $11.82 \pm 0.35$ & $11.98 \pm 0.34$ & $11.21 \pm 0.28$ & $43.38 \pm 0.67^{\mathrm{b}}$ \\
C18:1n7 & $46.10 \pm 0.81^{\mathrm{a}}$ & $46.40 \pm 0.59^{\mathrm{a}}$ & $45.31 \pm 0.78^{\mathrm{ab}}$ & $0.27 \pm 0.27$ \\
C18:2n6 & $0.00 \pm 0.00$ & $0.00 \pm 0.00$ & $0.34 \pm 0.34$ & $15.74 \pm 0.56^{\mathrm{a}}$ \\
C18:3n6 & $11.21 \pm 0.36^{\mathrm{b}}$ & $11.58 \pm 0.64^{\mathrm{b}}$ & $11.00 \pm 0.37^{\mathrm{b}}$ & $0.08 \pm 0.00^{\mathrm{a}}$ \\
C18:3n3 & $0.06 \pm 0.00^{\mathrm{bc}}$ & $0.06 \pm 0.00^{\mathrm{b}}$ & $0.05 \pm 0.00^{\mathrm{c}}$ & $0.91 \pm 0.05^{\mathrm{a}}$ \\
C20:1n9 & $0.44 \pm 0.01^{\mathrm{c}}$ & $0.57 \pm 0.04^{\mathrm{b}}$ & $0.46 \pm 0.01^{\mathrm{c}}$ & $0.89 \pm 0.03^{\mathrm{b}}$ \\
C20:4n6 & $1.03 \pm 0.03^{\mathrm{a}}$ & $1.04 \pm 0.04^{\mathrm{a}}$ & $1.06 \pm 0.05^{\mathrm{a}}$ & $0.45 \pm 0.02$ \\
SFA & $0.38 \pm 0.02$ & $0.43 \pm 0.02$ & $0.43 \pm 0.04$ & $35.30 \pm 0.48^{\mathrm{b}}$ \\
UFA & $37.80 \pm 0.69^{\mathrm{a}}$ & $36.97 \pm 0.52^{\mathrm{a}}$ & $37.71 \pm 0.52^{\mathrm{a}}$ & $64.70 \pm 0.48^{\mathrm{a}}$ \\
MUFA & $62.21 \pm 0.69^{\mathrm{b}}$ & $63.03 \pm 0.52^{\mathrm{b}}$ & $62.29 \pm 0.52^{\mathrm{b}}$ & $47.53 \pm 0.73^{\mathrm{b}}$ \\
PUFA & $50.11 \pm 0.81^{\mathrm{a}}$ & $50.39 \pm 0.61^{\mathrm{a}}$ & $50.35 \pm 0.70^{\mathrm{a}}$ & $17.17 \pm 0.60^{\mathrm{a}}$ \\
PUFA/SFA & $12.09 \pm 0.39^{\mathrm{b}}$ & $12.64 \pm 0.67^{\mathrm{b}}$ & $0.94 \pm 0.41^{\mathrm{b}}$ & $0.49 \pm 0.02^{\mathrm{a}}$
\end{tabular}

KNP, Korean native pig; LYD, (Landrace $\times$ Yorkshire) $+\times$ Duroc $^{\wedge}$; Ber, Berkshire; Du, Duroc; SFA, saturated fatty acids; UFA, unsaturated fatty acids; MUFA, monounsaturated fatty acids; PUFA, polyunsaturated fatty acids.

Means in the same row with different superscripts $(a, b, c)$ are significantly different $(\mathrm{p}<0.05)$.

Table 6. Texture properties of dry-cured hams processed from four different pig breeds $(\mathrm{n}=10)$

\begin{tabular}{lcccc}
\hline \multirow{2}{*}{ Texture } & \multicolumn{3}{c}{ Breed } \\
\cline { 2 - 5 } & \multicolumn{1}{c}{ KNP } & LYD & Ber & Du \\
\hline Hardness $(\mathrm{kg})$ & $9.15 \pm 1.26^{\mathrm{a}}$ & $6.03 \pm 0.77^{\mathrm{b}}$ & $5.14 \pm 0.52^{\mathrm{b}}$ & $5.13 \pm 0.62^{\mathrm{b}}$ \\
Cohesiveness & $0.49 \pm 0.01$ & $0.50 \pm 0.02$ & $0.46 \pm 0.03$ & $0.50 \pm 0.02$ \\
Springiness $(\mathrm{mm})$ & $14.95 \pm 0.57^{\mathrm{a}}$ & $13.67 \pm 0.78^{\mathrm{a}}$ & $11.32 \pm 0.64^{\mathrm{b}}$ & $11.89 \pm 0.40^{\mathrm{b}}$ \\
Gumminess $(\mathrm{kg})$ & $141.69 \pm 23.76^{\mathrm{a}}$ & $83.46 \pm 13.46^{\mathrm{b}}$ & $57.50 \pm 6.22^{\mathrm{b}}$ & $61.05 \pm 7.71^{\mathrm{b}}$ \\
Chewiness $(\mathrm{kg} \times \mathrm{mm})$ & $70.40 \pm 12.14^{\mathrm{a}}$ & $41.09 \pm 6.58^{\mathrm{b}}$ & $26.62 \pm 3.05^{\mathrm{b}}$ & $30.50 \pm 3.56^{\mathrm{b}}$ \\
\hline
\end{tabular}

KNP, Korean native pig; LYD, (Landrace $\times$ Yorkshire) $+\times$ Duroc $\$$; Ber, Berkshire; Du, Duroc.

Means in the same row with different superscripts $(a, b)$ are significantly different $(\mathrm{p}<0.05)$.

(Ruiz-Carrascal et al., 2000).

\section{Effect of breed on color parameter}

Table 7 shows instrumental color parameters $\left(\mathrm{L}^{*}, \mathrm{a}^{*}, \mathrm{~b}^{*}\right.$, chroma and $\mathrm{h}^{\circ}$ ) obtained from five different locations on the freshly cut surface of biceps femoris muscle. It was observed that breed significantly affects the color parameters of biceps femoris muscle of the hams. The $\mathrm{L}^{*}$ (lightness) values of the hams of Ber and Du breeds were significantly $(\mathrm{p}<0.05)$ higher than the values obtained from the hams of KNP and LYD breeds. Earlier workers (Hunt, 1980) found that the lightness is related to thin aqueous layer on the surface of muscle tissue which means that the levels of moisture and hydration affect the lightness of drycured ham. Therefore, it is possible that the higher moisture content in hams of Ber and Du breeds could be the factor for the higher lightness values of these hams. The KNP ham had higher CIE $a^{*}$ (redness) value than the LYD ham

Table 7. Color parameters of dry-cured hams processed from four different pig breeds $(n=10)$

\begin{tabular}{|c|c|c|c|c|c|}
\hline \multirow{2}{*}{ Item } & & \multicolumn{4}{|c|}{ Breed } \\
\hline & & KNP & LYD & Ber & $\mathrm{Du}$ \\
\hline \multirow[t]{3}{*}{ Color } & CIE L* & $35.18 \pm 0.81^{\mathrm{b}}$ & $37.66 \pm 1.33^{\mathrm{b}}$ & $41.26 \pm 1.54^{\mathrm{a}}$ & $44.37 \pm 0.78^{\mathrm{a}}$ \\
\hline & CIE $a^{*}$ & $11.50 \pm 0.53^{\mathrm{a}}$ & $10.01 \pm 0.34^{\mathrm{b}}$ & $10.70 \pm 0.35^{\mathrm{ab}}$ & $10.76 \pm 0.26^{\mathrm{ab}}$ \\
\hline & CIE b* & $6.20 \pm 0.20^{\mathrm{b}}$ & $6.72 \pm 0.41^{\mathrm{b}}$ & $6.80 \pm 0.25^{\mathrm{b}}$ & $8.82 \pm 0.49^{\mathrm{a}}$ \\
\hline \multicolumn{2}{|c|}{ Chroma } & $13.10 \pm 0.51^{\mathrm{ab}}$ & $12.10 \pm 0.46^{\mathrm{b}}$ & $12.72 \pm 0.32^{\mathrm{ab}}$ & $13.98 \pm 0.41^{\mathrm{a}}$ \\
\hline \multicolumn{2}{|c|}{ Hue angle $\left(h^{\circ}\right)$} & $28.56 \pm 1.09^{c}$ & $33.82 \pm 1.33^{\mathrm{b}}$ & $32.60 \pm 1.30^{\mathrm{b}}$ & $39.08 \pm 1.41^{\mathrm{a}}$ \\
\hline
\end{tabular}

KNP, Korean native pig; LYD, (Landrace $\times$ Yorkshire) $q \times$ Duroc $^{\wedge}$; Ber, Berkshire; Du, Duroc; CIE, Commission International de l'Eclairage.

Means in the same row with different superscripts $(a, b, c)$ are significantly different $(\mathrm{p}<0.05)$. 
$(\mathrm{p}<0.05)$. The CIE $b^{*}$ (yellowness) value of Du ham was significantly $(p<0.05)$ higher than the values of other breed hams whereas no differences in CIE $b^{*}$ values were observed between the KNP, LYD, and Ber hams ( $p>0.05)$. The hue angle value was highest in the dry-cured ham of Du breed, followed by the hams of Ber and LYD and KNP breeds. Color not only reflects the technological quality but also considerably influences saleability of meat and meat products, the color therefore may be the most important factor affecting the appearance and attractiveness of the products to consumers (Faustman and Cassens, 1990). Particularly, redness made up by nitrosylmyoglobin (MbFe(II)NO) is one of the most important color parameters for the cured-meat products such as dry-cured ham whereas the high lightness level is undesirable. Previous studies have reported that the color of dry-cured hams is influenced by a number of factors such as processing technology; dry-cured ham processed at higher drying temperature gives a more intense redness and yellowness (Andres et al., 2005); a long ripening time gives a more intense redness (Cilla et al., 2005). However, in the present study the processing conditions were kept same for all ham breeds therefore the difference in the color parameters of dry-cured hams is probably attributed due to differences in the muscle composition (e.g., moisture, fat and pigment contents) and oxidative status of the hams between the breeds. Again; from these results and previous reports, it can be concluded that breed is among the main factors affecting the color parameters of dry-cured hams.

\section{Effect of breed on sensorial parameters}

The results of sensory evaluation are shown in Table 8 . The breed had significant impact on the color, aroma and taste of the dry-cure hams. The panelists rated a higher color score for the dry-cured ham of KNP, followed by the ham of Ber, and the lowest score for the ham of Du breed. Additionally, higher aroma and taste scores were obtained in the dry-cured ham of KNP among the four selected breeds. On the other hand, the dry-cured ham of LYD breed had higher color and taste scores than the Du ham $(\mathrm{p}<0.05)$. MacLeod (1986) and Careri et al. (1993) reported that salt

Table 8. Sensory properties of dry-cured hams processed from four different pig breeds $(\mathrm{n}=10)$

\begin{tabular}{lcccc}
\hline \multirow{2}{*}{ Traits $^{1}$} & \multicolumn{4}{c}{ Breed } \\
\cline { 2 - 5 } & KNP & LYD & Ber & Du \\
\hline Color & $5.74 \pm 0.21^{\mathrm{a}}$ & $5.53 \pm 0.19^{\mathrm{ab}}$ & $5.14 \pm 0.13^{\mathrm{bc}}$ & $4.59 \pm 0.23^{\mathrm{c}}$ \\
Aroma & $5.69 \pm 0.10^{\mathrm{a}}$ & $4.97 \pm 0.17^{\mathrm{b}}$ & $4.57 \pm 0.33^{\mathrm{b}}$ & $4.40 \pm 0.29^{\mathrm{b}}$ \\
Taste & $5.76 \pm 0.11^{\mathrm{a}}$ & $5.17 \pm 0.23^{\mathrm{ab}}$ & $4.64 \pm 0.25^{\mathrm{bc}}$ & $4.26 \pm 0.27^{\mathrm{c}}$ \\
\hline KNP, Korean native pig; LYD, Landrace $\times$ Yorkshire) $+\times$ Duroc ${ }^{\uparrow} ;$ Ber, \\
Berkshire, Du, Duroc. \\
${ }^{1}$ Linear unstructured line scale from 0 (less) to 10 (more). \\
Means in the same row with different superscripts (a,b,c) are significantly \\
different (p<0.05).
\end{tabular}

concentrations, peptides and nucleotides are mainly responsible for the taste of meat products including drycured ham. While, the volatile compounds such as alcohols, aldehydes and aromatic hydrocarbons produced from the oxidation of fatty acids have been found responsible for the aroma attribute of dry-cured ham (Marusic et al., 2011). Previous studies have also reported that the high level of PUFAs cause undesirable flavor; off-flavor (Elmore et al., 2002; Ba et al., 2013) and negatively affect the texture of dry-cured ham (Ruiz-Carrascal et al., 2000).

On the other hand, studies have shown that the sensory parameters of dry-cured ham are also affected by a number of factors such as genetic lines (Muriel et al., 2004; Carrapiso and Garcia, 2008). Additionally, the processing technology (e.g., salting, ripening time and salt content) has also been found to greatly affect the sensory characteristics of dry-cured hams (Ruiz et al., 1998; Armenteros et al., 2012). Therefore, based on earlier studies it could be concluded that processing technology considerably affects the sensory parameters. In our study, we have kept all the above mentioned factors constant for processing of the hams but still observed a great variation in the sensorial parameters between the ham breeds. On the basis of present results it could be concluded that the differences in the sensory parameters among the ham breeds might be due to a genetic effect. Also, the difference in the IMF content between the hams of selected breeds is probably the main factor responsible for the variations in all the sensory parameters of dry-cured hams. Earlier workers (RuizCarracal et al., 2000; Ventanas et al., 2007; Fuentes et al., 2013) have also reported that the level of IMF content had positive effect on the sensory characteristics of dry-cured ham; hams with high IMF content generally produces higher score of sensory attributes.

In conclusion; in present study it was observed that the specific breed had a potential impact on the physicochemical composition, color and texture of drycured ham. The variations in the aforementioned parameters could be responsible for the difference in the sensorial characteristics of dry-cured hams of four selected pig breeds. On the basis of present results, the KNP pig breed emerged as the more suitable breed for manufacturing dry-cured ham with superior color and sensory quality, followed by the LYD, Ber, and Du breeds. However, our results also suggest that the processing technology should be suitably modulated for each pig breed in order to produce dry-cured hams with higher quality and economic benefits.

\section{ACKNOWLEDGMENTS}

The authors are grateful for the financial support of this work from "Cooperative Research Program for Agriculture Science \& Technology Development (Project No. 
PJ00879401 and PJ0059442002)" Rural Development Administration, Republic of Korea. We also would like to thank technical staffs at Animal Products Processing Factory, National Institute of Animal Science for valuable help.

\section{REFERENCES}

Andres, A. I., R. Cava, J. Ventanas, E. Muriel, and J. Ruiz. 2004. Lipid oxidative changes throughout the ripening of dry-cured Iberian hams with different salt contents and processing conditions. Food Chem. 84:375-381.

Andres, A. I., S. Ventanas, J. Ventanas, R. Cava, and J. Ruiz. 2005. Physicochemical changes throughout the ripening of dry cured hams with different salt content and processing conditions. Eur. Food Res. Technol. 221:30-35.

AOAC. 1995. Official Methods of Analysis. 16th ed. Association of Official Analytical Chemists. Washington, DC, USA.

AOAC. 2000. Official Mthods of Aalysi. 17th ed. Association of Official Analytical Chemists. Arlington, VA, USA.

Armenteros, M., M. C. Aristoy, R. M. Barat,and F. Toldrá. 2012. Biochemical and sensory changes in dry-cured ham salted with partial replacements of $\mathrm{NaCl}$ by other chloride salts. Meat Sci. 90:361-67.

Arnau, J., P. Gou, and J. Comaposada. 2003. Effect of the relative humidity of drying air during the resting period on the composition and appearance of dry-cured ham surface. Meat Sci. 65:1275-1280.

Ba, H. V., K. S. Ryu, and I. H. Hwang. 2012. Flavor Characteristics of Hanwoo Beef in Comparison with Other Korean Foods. Asian Austral. J. Anim. Sci. 25:435 -446.

Ba, H. V., A. Touseef, and I. H. Hwang. 2013. Significant influence of particular unsaturated fatty acids and $\mathrm{pH}$ on the volatile flavor compounds in meat-like model systems. Meat Sci. 94:480-488.

Bendall, J. R. 1973. Postmortem changes in muscle. In: Structure and Function of Muscle (Ed. G. H. Bourne). Academic Press, NY, USA. pp. 243-309.

Cai, J., Q. Chen, X. Wan, and J. Zhao. 2011. Determination of total volatile basic nitrogen (TVB-N) content and WarnerBratzlershear force (WBSF) in pork using Fourier transform near infrared (FT-NIR) spectroscopy. Food Chem. 126:13541360.

Cameron, N. D., P. D. Warriss, S. J. Porter, and M. B. Enser. 1990. Comparison of Duroc and British landrace pigs for meat and eating quality. Meat Sci. 27:227-247.

Careri, M., A. Mangia, G. Barbieri, L. Bolzoni, R. Virgili, and G. Parolari. 1993. Sensory property relationship to chemical data of Italian type dry-cured ham. J. Food Sci. 58:968-972.

Carrapiso, A. I. and C. Garcia. 2008. Effect of the Iberian pig line on dry-cured ham characteristics. Meat Sci. 80:529-534.

Cilla, I., L. Martınez, J. A. Beltran, and P. Roncales. 2005. Factors affecting acceptability of dry-cured ham throughout extended maturation under "bodega" conditions. Meat Sci. 69:789-795.

Comaposada, J., P. Gou, and J. Arnau. 2000. The effect of sodium chloride content and temperature on pork meat isotherms. Meat Sci. 55:291-295.

Elmore, J. S., M. M. Campo, M. Enser, and D. S. Mottram. 2002.
Effect of lipid composition on meat-like model systems containing cystein, ribose and polyunsaturated fatty acids. J. Agric. Food Chem. 50:1126-1132.

Faustman, C. and R. G. Cassens. 1990. The biochemical basis for discoloration in fresh meat: A review. J. Muscle Foods 1:217243.

Fuentes, V., J. Ventanas, D. Morcuende, and S. Ventanas. 2013. Effect of intramuscular fat content and serving temperature on temporal sensory perception of sliced and vacuum packaged dry-cured ham. Meat Sci. 93:621- 629.

Gandemer, G. 2002. Lipids in muscles and adipose tissues, changes during processing and sensory properties of meat products. Meat Sci. 62:309-321.

Gandemer, G. 2009. Dry cured ham quality as related to lipid quality of raw material and lipid changes during processing: A review. Grasas y Aceites.60:297-307.

Garcia-Gil, N., E. Santos-Garces., I. Munoz., E. Fulladosa., J. Arnau and P. Gou. 2012. Salting, drying and sensory quality of dry-cured hams subjected to different pre-salting treatments: Skin trimming and pressing. Meat Sci. 90:386-392.

Gil, M., M. I. Delday, M. I. Gispert, M. F. Furnols, C. M. Maltin, G. S. Plastow, R. Klont, A. A. Son, and D Carrion. 2008. Relationships between biochemical characteristics and meat quality of longissimusc thoracis and semimembranosus muscles in five porcine lines. Meat Sci. 80:927-933.

Honikel, K. O. 2008. The use and control of nitrate and nitrite for the processingof meat products. Meat Sci. 78:68-76.

Hunt, M. C. 1980. Meat color measurements. Proceedings of 33rd Annual Reciprocal Meat Conference Chicago.

Isabel, B., C. J. Lopez-Bote, A. I. Rey, and R. S. Arias. 1999. Influence of dietary a-tocopheryl acetate supplementation of pigs on oxidative deterioration and weight loss in sliced drycured ham. Meat Sci. 51:227-232.

Jimenez-Colmenero, F., J. Ventanas, and F. Toldrá. 2010. Nutritional composition of dry cured ham and its role in a healthy diet. Meat Sci. 84:585-593.

Jurado, A., C. Garcia., M. L. Timon, and A. I. Carrapiso. 2007. Effect of ripening time and rearing system on amino acidrelated flavor compounds of Iberian ham. Meat Sci. 75:585594.

Keran, H., A. Salkic, A. Odobasic, M. Jasic, N. Ahmetovic, and I. Sestan. 2009. The importance of determination of some physical - chemical properties of wheat and flour. Agric. Conspec. Sci. 74:197-200.

Lee, S. H., J. H. Choe, Y. M. Choi, K. C. Jung, M. S. Rhee, K. Hong, S. K. Lee, S. Y. C. Ryu, and B. C. Kim. 2012. The influence of pork quality traits and muscle fiber characteristics on the eating quality of pork from various breeds. Meat Sci. 90:284-291.

MacLeod, G. 1986. The scientific and technological basis of meat flavours. In: Developments in Food Flavours (Eds. G. G. Birch and M. G. Lindley). Elsevier, London, UK. pp. 191-223.

Marusic, N., M. Petrovic, S. Vidacek, T. Petrak, and H. Medic. 2011. Characterization of traditional Istrian dry-cured ham by means of physical and chemical analyses and volatile compounds. Meat Sci. 88:786-790.

Meinert, L., S. C. Christiansen, L. Kristensen, C. Bjergegaard, and M. D. Aaslyng. 2008. Eating quality of pork from pure breeds and DLY studied by focus group research and meat quality 
analyses. Meat Sci. 80:304-314.

Min, J. S., S. O. Lee, A. Jang, C. Jo, C. S. Park, and M. Lee. 2007. Relationship between the concentration of biogenic amines and volatile basic nitrogen in fresh beef, pork, and chicken meat. Asian Austral. J. Anim. Sci. 20:1278-1284.

Muriel, E., J. Ruiz, D. Martın, M. J. Petron, and T. Antequera. 2004. Physico-chemical and sensory characteristics of drycured loin from different Iberian pig lines. Food Sci. Technol. Int. 10:117-123.

Parolari, G., R. Virgili, and C. Schivazappa. 1994. Relationship between cathepsin B activity and compositional parameters in dry-cured hams of normal and defective texture. Meat Sci. $38: 117-122$.

Pastorelli, G., S. Magni, R. Rossi, E. Pagliarini, P. Baldini, P. Dirinck, F. V. Opstaele, and C. Corino. 2003. Influence of dietary fat, on fatty acid composition and sensory properties of dry- cured Parma ham. Meat Sci. 65:571-580.

Resano, H., A. I. Sanjuan, and L. M. Albisu. 2007. Consumers' acceptability of cured ham in Spain and the influence of information. Food Qual. Prefer. 18:1064-1076.

Ramirez, M. R. and R. Cava. 2008. Effect of Iberian $\times$ Duroc genotype on composition and sensory properties of dry-cured ham. J. Sci. Food Agric. 88:667-675.

Ruiz-Carrascal, J., J. Ventanas, R. Cava, A. I. Andres, and C. Garcia. 2000. Texture and appearance of dry cured ham as affected by fat content and fatty acid composition. Food Res Int. 33:91- 95.
Ruiz-Ramirez, J., J. Arnau, X. Serra, and P. Gou. 2006. Effect of $\mathrm{pH}_{24}, \mathrm{NaCl}$ content and proteolysis index on the relationship between water and texture parameters in biceps femoris and semimembranosus muscles in dry-cured ham. Meat Sci. 72:185-194.

Ruiz, J., J. Ventanas, R. Cava, M. L. Timon, and C. Garcia. 1998. Sensory characteristics of Iberian ham: influence of processing time and slice location. Food Res. Int. 31:53-58.

Santos, C., L. Hoz, M. I. Cambero, M. C. Cabeza, and J. A. Ordoñez. 2008. Enrichment of dry-cured ham with $\alpha$-linolenic acid and $\alpha$-tocopherol by use of linseed oil and $\alpha$-tocopheryl acetate. Meat Sci. 80:668-674.

SAS Institute Inc. 2007. SAS User's Guide. Release. 9.1.3. Statistical Analysis System Institute. Cary, NC, USA.

Tapiero, H. and K. D. Tew. 2003. Trace elements in human physiology and pathology: zinc and metallothioneins. Biomed. Pharmacother. 57:399-411.

Ventanas, S., J. Ventanas, J. Tovar, C. García, and M. Estevez. 2007. Extensive feeding versus oleic and tocopherol enriched mixed diets for the production of Iberian dry-cured hams: Effect on chemical composition, oxidative status and sensory traits. Meat Sci. 77:246- 256.

Ventanas, S., M. Estevez, J. F. Tejeda, and J. Ruiz. 2006. Protein and lipid oxidation in longissimus dorsi and dry cured loin from Iberian pigs as affected by crossbreeding and diet. Meat Sci. 72:647-655. 